\title{
Production Studies of a Guinea Fowl Variety of Hungarian Origin in the Tropical Regions of Vietnam
}

\author{
By Kisne Do Thi Dong Xuan* \\ Istvan Szalay \\ Phung Duc Tien \\ Pham Thi Minh Thu ${ }^{+}$ \\ Thieu Ngoc Lan Phuong
}

Guinea fowl is considered a Hungarian poultry species, which adapted a long time ago, with excellent meat quality, very good ability to acclimatise to different conditions, resistance, wild and seeking habits with low costs of keeping, which make guinea fowl one of the best poultry species for natural production. In 2002, the Association of Hungarian Small Animal Breeders for Gene Conservation (MGE) and Institute for Small Animal Research, previously named HaGK - Research Centre for Farm Animal Gene Conservation (KÁTKI) exported the first guinea-fowl population to Vietnam for adaptation study with regards to the indigenous animal genetic conservation. At first, the guinea fowl was experimentally reared in the Poultry Research Centre (POREC), located in the subtropical region of North Vietnam. Following the success of this adaptation experiment, the present study aimed to contribute to the expansion of the old Hungarian guinea fowl to tropical regions in South Vietnam (Dong Nai and the Mekong Delta). During the 13th week rearing period the mortality rate of guinea fowls was lower than $3 \%$ in both regions. The average body weight and the feed conversion of guinea fowls recorded in Dong Nai and the Mekong Delta, during the 13rd week were $1269 \pm 64 \mathrm{~g}(n=487)$ vs $1610 \pm 64 \mathrm{~g}$ $(\mathrm{n}=489 ; \quad P<0.05)$ respectively and $3.43 \mathrm{vs} 2.92 \mathrm{~kg}$ feed $/ \mathrm{kg}$ body weight gain $(P<0.001)$ respectively. In Dong Nai, the egg production reached $71 \%$ (1205 eggs/242 hens/week) and hatchability ranged between 31\% (61/200) and 72\% (495/690). Despite differences of performance between groups, results show successful adaptation of guinea fowls to underprivileged regions of South Vietnam. This study could be the first step for further integrating the Hungarian guinea

\footnotetext{
*Senior Researcher, Research Centre for Farm Animal Gene Conservation, Hungary.

${ }^{\dagger}$ Scientific Consultant, Research Centre for Farm Animal Gene Conservation, Hungary.

${ }^{\ddagger}$ Director, NIAH Poultry Research Centre, Vietnam.

${ }^{+}$Senior Researcher, NIAH Poultry Research Centre, Vietnam.

'PhD Student, Research Centre for Farm Animal Gene Conservation, Hungary.
} 
fowl into the local poultry production and could also help the Vietnamese farmers raise extra income as well as improve their living standard sustainably.

\section{Introduction}

Originating from Africa, the guinea fowl is considered an adapted poultry species in Europe, including Hungary. It adapted a long time ago (Szalay et al., 2009; Szücs and Szalay, 2011). Characterised by excellent meat quality, very good ability to adapt to different conditions, resistance and wild habit, the guinea fowl can be considered as one of the best poultry species for low input extensive farming and natural production in different environments (Szalay et al., 2004). Majority of related papers reveal, that the guinea fowl is a reliable contributor to the livelihood of rural people, who keep the birds mostly in scavenging systems, however, substantial improvement of productivity, reproducing ability, animal health and liveability is needed (e.g. Boko et al., 2011; Moreki and Radikara, 2013), and research needs to be done to assess genetic characteristics, production and reproduction traits of local varieties for future use, either in Africa (Kusina et al., 2012; Agbolosu et al., 2012), or in European countries (Bawej et al., 2012; Dodu and Czirjak, 2012; Váradi et al., 2013).

Studies of guinea fowl breeding and production in Vietnam was initiated by the Association of Hungarian Small Animal Breeders (MGE), the official breeding organisation of Old Hungarian poultry breeds (Szalay, 2002), including guinea fowls. In 2002, MGE and the Institute for Small Animal Research (KÁTKI, the previous name of HáGK - Research Centre for Farm Animal Gene Conservation) exported the first guinea-fowl population to Vietnam for an adaptation study (Dong Xuan and Szalay, 2007). The basic concept about introducing Hungarian guinea fowl into Vietnam has always been determined by sustainability and gene conservation factors (Dong Xuan and Szalay, 2003; Szalay et al., 2003; Dong Xuan et al., 2004). Guinea fowl is considered an exotic breed in Vietnam. There are no previous local breeding stocks of guinea-fowl in Vietnam. Being a distinct species from the domestic fowl (Gallus domesticus) Guinea fowl (Numida meleagris) has no harmful effect on the local flocks of chicken, as occasional crossings of guinea fowl and local chickens have no reproductive ability (Szalay and Dong Xuan, 2007).

Old Hungarian guinea fowl, maintained and conserved under the HU-BA system in Hungary (HU-BA is the Hungarian abbreviation of Hungaricum poultry) was first imported and experimentally reared in the Poultry Research Centre (POREC), located in the sub-tropical region of North Vietnam. Following the success of this adaptation experiment (Tien et al., 2007; Tien et al., 2010), the present study aimed to compare the performance of Hungarian guinea fowl reared in two different regions of South Vietnam. The ultimate objective was to expand breeding of Hungarian guinea fowl to tropical regions in South Vietnam, with special regards to the conservation of local poultry 
genetic resources. Dong Nai and the Mekong Delta, where many underprivileged areas exist, were chosen to carry out these studies. Can Tho University (CTU) was invited to participate as an important education centre which would help to study deeply the rearing and breeding procedure of guinea-fowls as well as integrate the Mekong Delta's local family farms into guinea fowl breeding.

\section{Materials and Methods}

\section{Animals}

One thousand day old Hungarian guinea fowl chicks were randomly divided into 2 groups (500-500) and sent from Cam Binh station (POREC) to Dong Nai (Trang Bom region - Loc Vung farm) and the Mekong Delta (Can Tho University). Breeding technology and related information of guinea fowl were given to the local "test-keepers" by POREC experts. The whole study was under the supervision of MGE's experts.

\section{Experimental Design}

\section{Experiments in Dong Nai}

Five hundred guinea fowls were kept in an extensive system utilizing homemade pens, built by the farm owners. Commercial chicken feed was used throughout the study. Data of mortality, live body weight and feed consumption were weekly recorded during the first 13 weeks of age.

Later, the breeding of guinea fowls was expanded to the under-privileged southwest counties of Vietnam. Local Vietnamese agricultural researchers were invited to join local farmers as a working unit to investigate the adaptation process and develop a low-input but profitable local keeping system for guinea fowls. Egg production and hatchability were also studied in subsequent trials of extensive experimental keeping systems (free range and backyard keeping) at the local family/small-scale farms.

\section{Experiments in Mekong Delta}

The remaining 500 guinea fowls were divided into different groups for undergraduate and post-graduate students of CTU to investigate the productive traits under the Mekong Delta's tropical climate conditions and various keeping and nutritional technologies. Commercial chicken feed with supplemented green fodders (Eichhornia crassipes) was used throughout the study. Mortality, body weight and feed consumption of guinea fowl, including the green fodders, were also weekly recorded during the rearing period.

\section{Statistical Analysis}

The difference between mortality rates was evaluated using the $\chi$-square test. The body weight, feed consumption and feed conversion were tested at $6^{\text {th }}$ and $13^{\text {rd }}$ weeks using factorial ANOVA. 


\section{Results \& Discussion}

During the $13^{\text {th }}$ week rearing period, the mortality rate of guinea fowls was $2.6 \%$ (13/500) in Dong Nai and 2.2\% (11/500) in the Mekong Delta, showing no difference ( $\mathrm{P}>0.05$ between the two groups). The average body weight of guinea fowls recorded in Dong Nai and the Mekong Delta was $601 \pm 30 \mathrm{~g}$ $(\mathrm{n}=490)$ and $590 \pm 24 \mathrm{~g}(\mathrm{n}=493 ; \mathrm{P}>0.05)$ at 6 weeks of age, respectively; $1269 \pm 63 \mathrm{~g}(\mathrm{n}=487)$ and $1610 \pm 64 \mathrm{~g}(\mathrm{n}=489 ; \mathrm{P}<0.05)$ at 13 weeks of age respectively (Figure 1).

Figure 1. Progress of the Average Weekly Body Weight of Guinea Fowls during 13 Weeks of Rearing in Dong Nai and in the Mekong Delta.

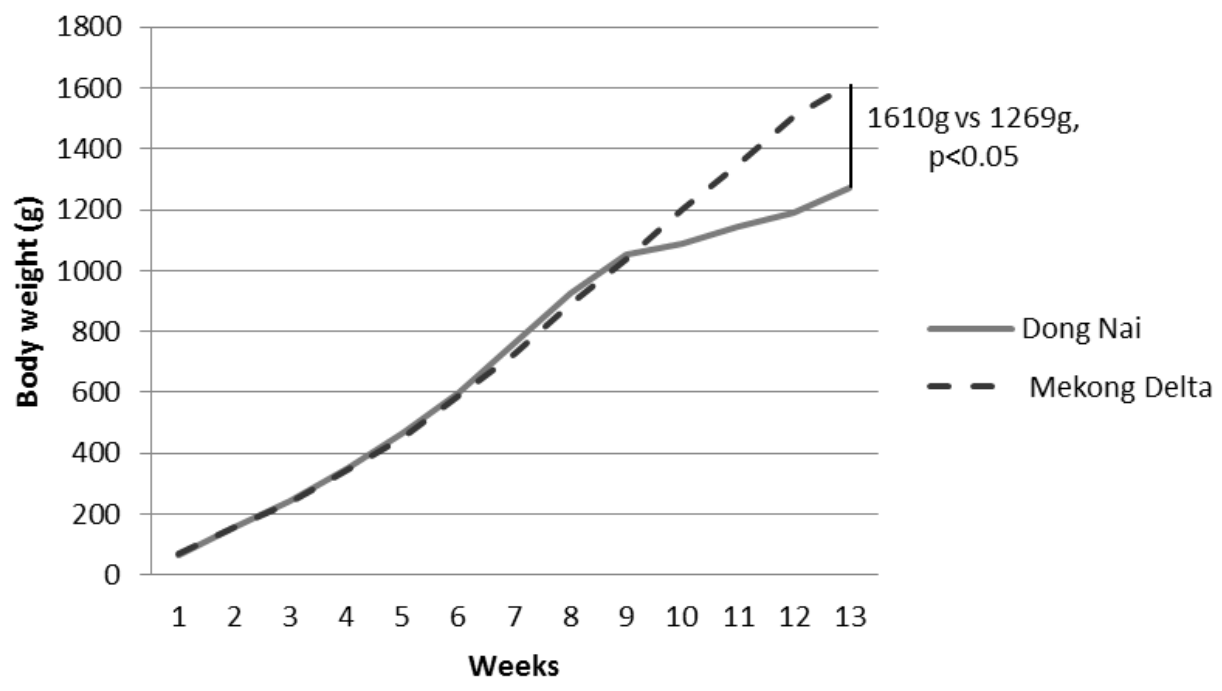

The feed consumption of guinea fowls reared in Dong Nai and the Mekong Delta was $1183 \mathrm{~kg} \pm 47 \mathrm{~g} /$ guinea fowl; $1038 \pm 42 \mathrm{~g} /$ guinea fowl, respectively at 6 weeks of age $(\mathrm{P}>0.05)$ and $4130 \pm 165 \mathrm{~g}$ and $4499 \pm 180 \mathrm{~g} / \mathrm{guinea}$ fowl, respectively at 13 weeks of age $(\mathrm{P}<0.001)$. The feed conversion of guinea fowls, recorded in Dong Nai was always higher than in the Mekong Delta (at 6 weeks of age: $2.21 \mathrm{vs} .1 .99 \mathrm{~kg}$ feed/ $/ \mathrm{kg}$ body weight gain, $\mathrm{P}<0.05$; at 13 weeks of age: 3.43 vs. $2.92 \mathrm{~kg}$ feed $/ \mathrm{kg}$ body weight gain, $\mathrm{P}<0.001)$. The average feed consumption per week and feed conversion of guinea fowls during the whole experiment are showed in Figure 2 and Figure 3, respectively. At $13^{\text {rd }}$ week, the average body weight of guinea fowls reared in the Mekong Delta was higher and the feed conversion was lower than of those reared in Dong Nai. These results show that guinea fowls adapted better in the Mekong Delta than in Dong Nai. The supplementation of green fodders in the diet might contribute to better performance of guinea fowls kept in the Mekong Delta. 
Figure 2. Weekly Feed Consumption of Guinea Fowls during 13 Weeks Rearing in Dong Nai and in the Mekong Delta

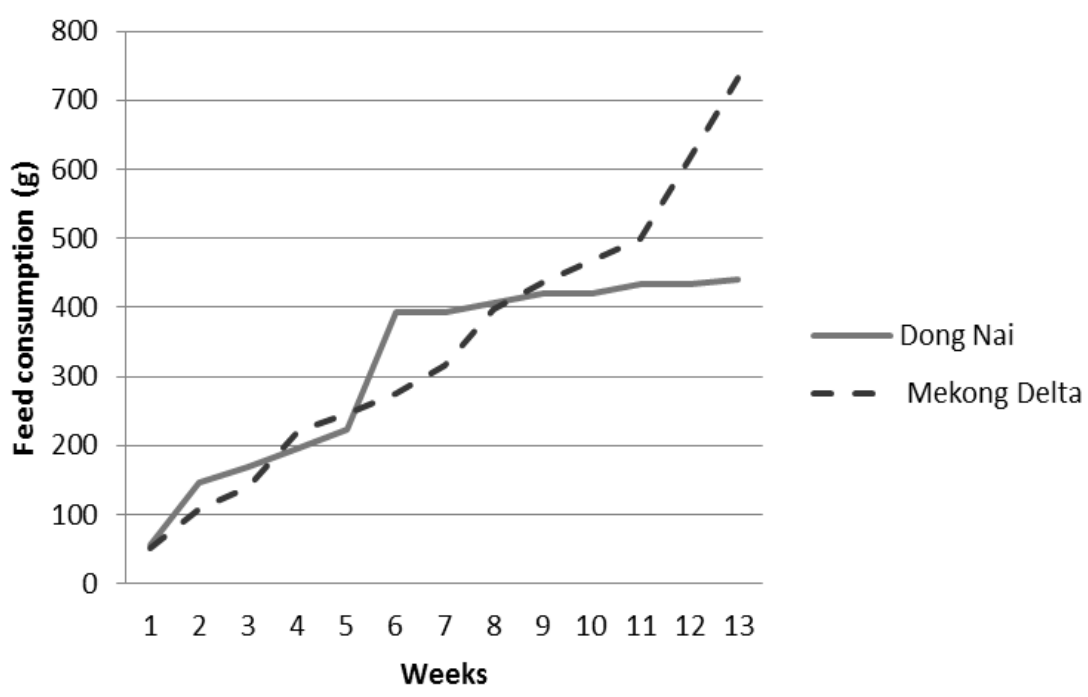

Figure 3. Feed Conversion of Guinea Fowls in Dong Nai and in the Mekong Delta

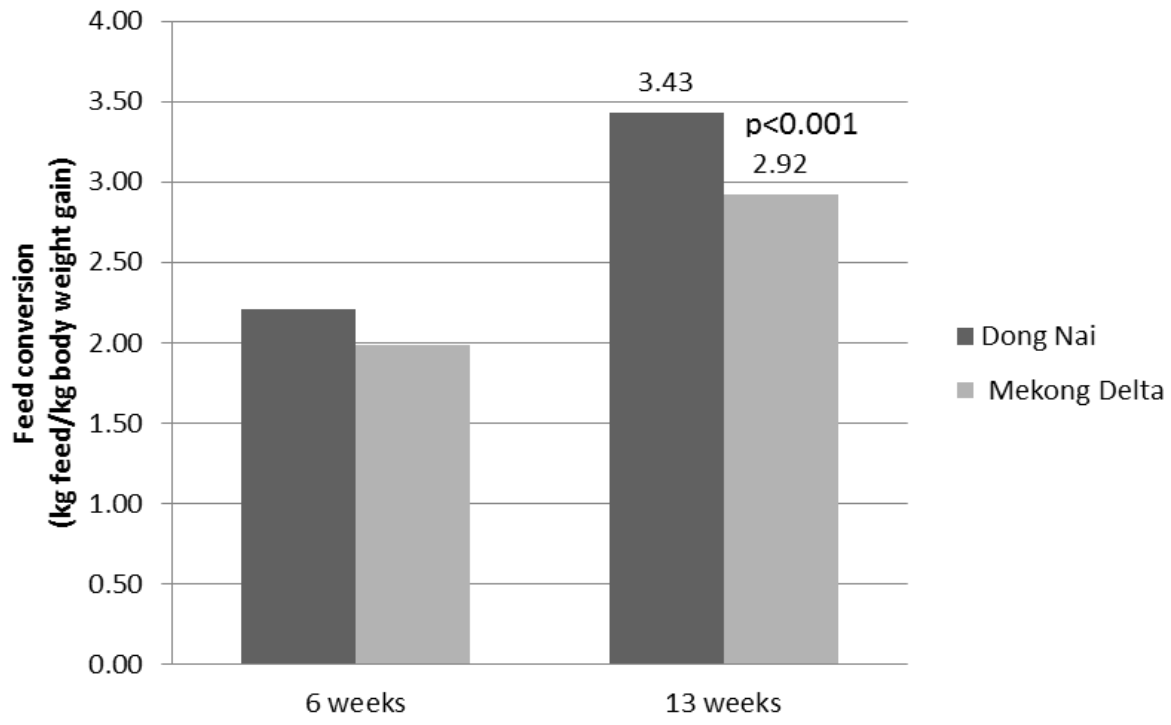


Additional data for egg production and hatchability, studied in the local farms of Dong Nai region are shown in Figures 4 and 5.

Figure 4. Egg Production of Guinea Fowls in Dong Nai.

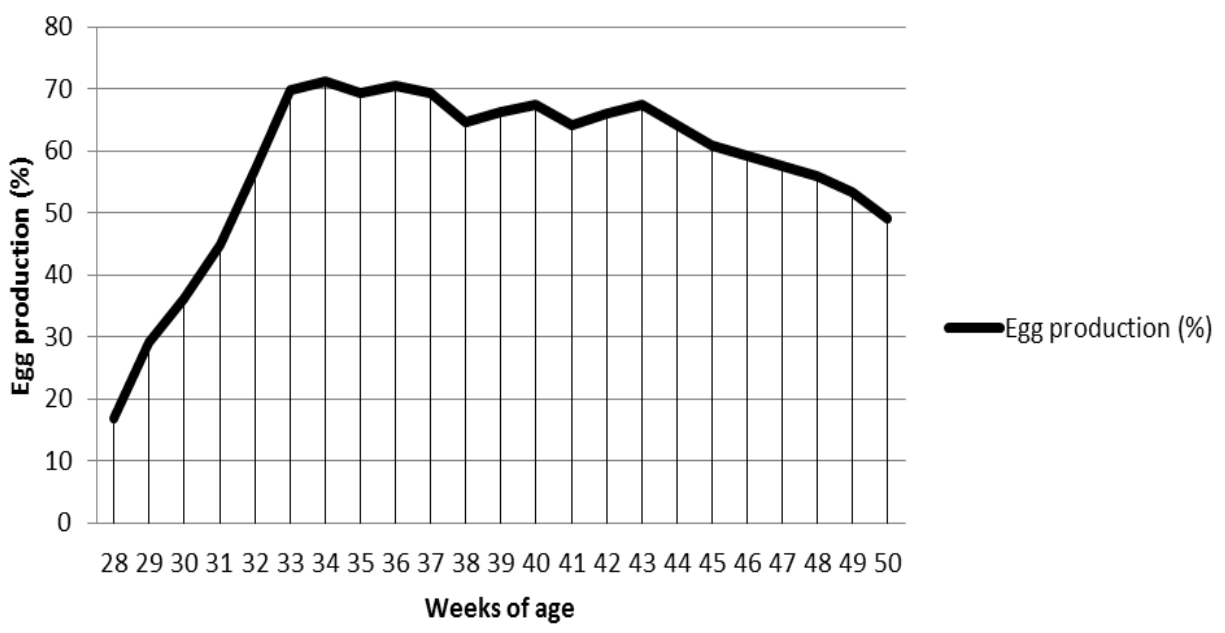

Figure 5. Hatchability of Guinea Fowls' Eggs in Dong Nai

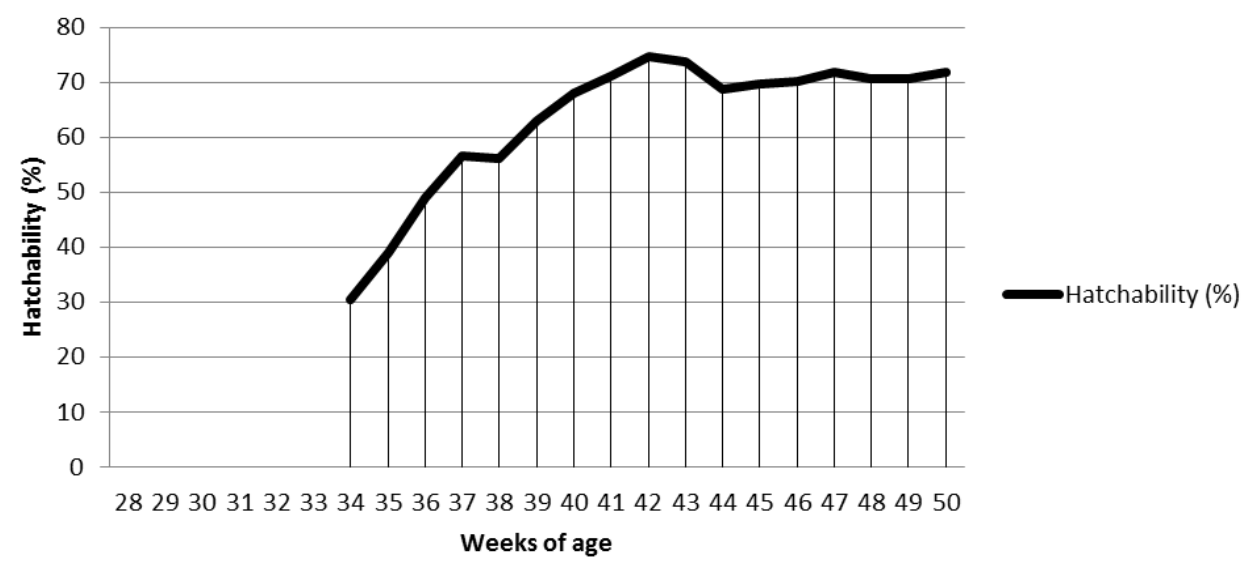

The egg production of guinea fowls reared in Dong Nai suggests a relatively good adaptability by reaching $71.1 \%$ (1205 eggs/242hens/week). Hatchability of guinea fowl eggs produced in Dong Nai ranged between $30.5 \%$ $(61 / 200)$ and $71.74 \%$ (495/690).

Less favourable results of rearing guinea fowls in Dong Nai than in experimental farms of CTU could be also explained due to the lack of experiences and limited budgets for feeding. However, the low mortality proved high adaptation potential of guinea fowl to the South Vietnam's climate. The feed consumption was comparable and the average body weight was acceptable comparing to the result recorded at POREC (1.07-1.12 kg and 603-612 g respectively) at 6 weeks of age (Tien et al., 2007). Based on the results of this study accomplished in Dong Nai and the Mekong Delta, it was suggested that Hungarian guinea fowl can be also reared in South Vietnam 
with success. In fact, in the last decade, guinea fowl production has been developed in many provinces of North Vietnam such as Ha Noi, Nam Dinh, Soc Son, Vinh Phuc, Thanh Hoa, Yen Bai, Da Nang and was rated as one of the possible specialities of Vietnam's future poultry production with the price of 1.5 - 2 times higher than that of commercial chicken products (Tien et al., 2007). Results are well comparable with those obtained earlier in NorthVietnam (Tien et al., 2007; 2010) and in Hungary for the same variety of guinea fowl (Szalay et al., 2004; Dong Xuan et al., 2009), or recently in African or other European countries for local varieties (e.g. Kusina et al., 2012; Dodu and Czirjak, 2012).

\section{Conclusions \& Recommendations}

During the $13^{\text {th }}$ week rearing period, all the results of mortality rate, average body weight and feed conversion of guinea fowl recorded in two different places show successful adaptation of guinea fowls to underprivileged regions of South Vietnam, with a somewhat better performance in the Mekong Delta. This study is considered to be the first step for integrating this species into the local poultry production, helping the Vietnamese farmers to raise extra income as well as to improve their living standards sustainably. However, further studies are needed to improve the fertility, hatchability, and local nutritional regimes of guinea fowl eggs among tropical conditions of South Vietnam, as well as to establish a local but long lasting market for guinea fowl in the country.

\section{Acknowledgments}

Our thanks are expressed to the "Ministry of Foreign Affairs of Hungary" for financial support.

\section{References}

Agbolosu, A.A., Teye, G.A., Jebuni, S.N., Ansah, T., Naandam, J. 2012: Comparative study of growth and laying performance of indigenous layer guinea fowls (Numida meleagris) from Upper East, Upper West and Northern Regions of Ghana. Agric. Biol. J. N. Am. 3(9), 354-359.

Bawej, M., Kokoszyński, D., Bernacki, Z. 2012: Evaluation of genetic similarity between white and grey varieties of Guinea fowl (Numida meleagris). Journal of Central European Agriculture, 13(4), 654-661.

Boko, C.K., Kpodekon, M.T., Farougou, S., Dahouda, M., Youssao, A.K.I., Aplogan, G.L., Zanou, J., Mainil, J.G. 2011: Farmer perceptions and pathological constraints in helmeted guinea fowl farming in the Borgou department in NorthEast Benin. African Journal of Agricultural Research, 6 (10), 2348-2357. 
Dodu, M.A., Czirjak Zs. 2012: Aspects regarding the incubation process of Guinea fowl population (Numida meleagris) from Bihor county. Analele Universităţii din Oradea, $45-50$.

Dong Xuan, K.D.T, Szalay, I., Su, V.V., Tieu, H.V., Vang, N. D. 2004: AnGR conservation strategies to develop low input mixed farming in South-East Asia. DAGENE Meeting, Bled (Slovenia, 2. September, 2004).

Dong Xuan, K.D.T. and Szalay, I.T. 2003: Possibilities and aspects to introduce foreign poultry genetic resources to Central Vietnam. In: Proceedings of the $3 \mathrm{rd}$ Vietnamese-Hungarian Conference on "Domestic animal production and aquaculture - Quality and rural development", pp. 47-54.

Dong Xuan, K.D.T. and Szalay, I.T. 2007: Agricultural Research for Development (ARD)-Trilateral Hungarian-Vietnamese-Lao sample to develop poultry breeding in South-East Asia. In: Proceedings of the 5th Vietnamese-Hungarian international conference on animal production and aquaculture for sustainable farming (Can Tho University, Can Tho, Vietnam, 11-15 august, 2007), pp. 1-5.

Dong Xuan, K.D.T; Szalay, I., Tien, P.D., Thu, P.T.M. 2009: Régi magyar baromfifajtáink Délkelet-Ázsiában. [Old Hungarian Poultry Breeds in SoutheastAsia - in Hungarian] Magyar Állattenyésztők Lapja [Journal of Hungarian Animal Breeders], 37 (11), 8.

Kusina, N.T., Saina, H., Lebel, S. 2012: An insight into guinea fowl rearing practices and productivity by guinea fowl keepers in Zimbabwe. African Journal of Agricultural Research, 7 (25), 3621-3625.

Moreki, J.C., Radikara, M.V. 2013: Challenges to Commercialization of Guinea Fowl in Africa. International Journal of Science and Research, 2 (11), 436-440.

Szalay I., Barna J., Körösiné Molnár, A. 2004: A gyöngytyúk. [The Guinea-fowl -in Hungarian] Mezőgazda Publishing (Budapest, Hungary), pp. 152. ISBN: $963-$ 286-148-5

Szalay I., Donng Xuan, K.D.T, Virág, Gy., Szentes, K.Á., Bódi, L. 2009: Prospects for conserving traditional poultry breeds of the Carpathian Basin. AWETH, 5 (2), $119-148$.

Szalay, I. 2002: Old Hungarian poultry (Régi magyar baromfifajták) [In Hungarian and English]. Mezőgazda Publishing (Budapest, Hungary). pp. 111. ISBN: 978963-935-834-8

Szalay, I., Ferencz, T.R., Kiss-Pető, T., Dong Xuan, K. D. T. 2003: The need and advantage of genetic resources in sustainable agriculture and high quality poultry production - A Hungarian approach. In: Proceedings of the 3rd VietnameseHungarian Conference on "Domestic animal production and aquaculture Quality and rural development”, pp. 20-34.

Szalay, I.T. and Dong Xuan, K. D. T. 2007: Sustainability and gene conservation as guiding principles of the Hungarian-Vietnamese Poultry Research for Development. In: Proceedings of the 5th Vietnamese-Hungarian international conference on animal production and aquaculture for sustainable farming (Can Tho University, Can Tho, Vietnam, 11-15 august, 2007), pp. 21-25.

Szücs, E., Szalay, I. 2011: Indigenous farm animal breeds in Hungary. In E. Szücs, Sz. Konrád \& E.N. Sossidou (eds.) Basics of Animal Welfare \& Product Quality. Szent István Univ. Gödöllő, pp. 131-151. ISBN 978-963-269-143-5

Tien, P.D, Oanh, N.T.K, Thu, P.M.T, Loc, H.V., Tinh, N.T. 2010: Selection for improvement of production of 3 guinea fowl lines after 3 generations. In: Proceedings of the 14th AAAP Animal Science Congress (Pingtung, Taiwan, ROC, 23-27 August, 2010), pp. 66-69. 
Tien, P.D, Thu, P.M.T, Dong Xuan, K.D.T, Szalay, I., Oanh, N.T.K, Loc, H.V., Huong, T.T. 2007: Study on selection for improvement of three guinea fowl lines' production through three generations. In: Proceedings of the 5th Vietnamese-Hungarian international conference on animal production and aquaculture for sustainable farming (Can Tho University, Can Tho, Vietnam, 1115 August, 2007), pp. 66-74.

Váradi, É., Végi, B., Liptói, K., Barna, J. 2013: Methods for Cryopreservation of Guinea Fowl Sperm. PLOS ONE 8 (4). 
